ISSN: 2302-8556

\title{
Penerapan Balanced Scorecard Pada Pengukuran Kinerja PT. Blue Bird Tbk.
}

\author{
Noviana Hermanus Djo ${ }^{1}$ \\ Ida Bagus Dharmadiaksa ${ }^{2}$
}

\author{
${ }^{1,2}$ Fakultas Ekonomi dan Bisnis Universitas Udayana (Unud), Bali, Indonesia \\ e-mail: novihermanus@gmail.com
}

\begin{abstract}
ABSTRAK
Variabel dari penelitian ini adalah empat perspektif Balanced Scorecard yaitu perspektif keuangan yang bertolok ukur ROI, perencanaan perusahaan, pengawasan dan pengendalian perusahaan, perspektif pelanggan yang bertolok ukur keandalan, cepat tanggap, jaminan, empati dan kasat mata, perspektif proses bisnis internal yang bertolok ukur inovasi, operasi dan pasca penjualan, perspektif pembelajaran dan pertumbuhan bertolok ukur kepuasan kerja dan motivasi karyawan. Hasil dari keempat perspektif mengindikasikan bahwa kinerja PT. Blue Bird Tbk. ditinjau dari: (1) perspektif keuangan adalah kurang baik dengan ROI yang setiap tahun mengalami penurunan namun pengelolaannya baik, (2) perspektif pelanggan adalah baik dengan pelanggan merasa puas dengan keandalan, cepat tanggap, jaminan, empati, dan kasat mata, (3) perspektif proses bisnis internal adalah baik dengan adanya inovasi, operasi dan pasca penjualan yang baik, (4) perspektif pembelajaran dan pertumbuhan adalah baik dengan adanya kepuasan dan motivasi karyawan.

Kata kunci: Balanced scorecard, pengukuran kinerja, perspektif keuangan, perspektif pelanggan
\end{abstract}

\begin{abstract}
The variables of this study are the four perspectives of the Balanced Scorecard, which are financial perspectives that are measured by ROI, corporate planning, supervision and control of the company, customer perspectives that are measured by reliability, responsiveness, assurance, empathy and invisible, internal business process perspectives that measure innovation, operations and post-sales, learning and growth perspectives are measured by job satisfaction and employee motivation. Results from the four perspectives indicate that the performance of PT. Blue Bird Tbk. In terms of: (1) financial perspective is not good with ROI which decreases every year but management is good, (2) customer perspective is good with customers satisfied with reliability, responsiveness, assurance, empathy, and invisible, (3) internal business process learning and growth perspective is good with the satisfaction and motivation of employees.

Keywords: Balanced scorecard, performance measurement, financial perspective, customer perspective
\end{abstract}

\section{PENDAHULUAN}

Taksi PT. Blue Bird Tbk. menjadi pionir layanan taksi berbasis pemesanan melalui telepon dan aplikasi mobile melalui layanan My Blue Bird. Dengan ini, pengguna aplikasi My Blue Bird atau Go-Blue Bird cukup memesan taksi baik secara aplikasi mobile secara online maupun telepon dan nantinya akan dijemput 
oleh supir taksi yang merespon pesanan pengguna atau calon penumpang. Transaksi pembayaran dilakukan saat pengguna sampai ke tujuan kepada supir taksi. Tarif yang dikenakan bervariasi berdasarkan jarak yang ditempuh atau berdasarkan flat rate yang diberlakukan. Akan tetapi bukan hanya PT. Blue Bird Tbk. sendiri yang bergerak di bidang jasa transportasi ini, beberapa perusahaan yang menjadi pesaing keras PT. Blue Bird Tbk. adalah Gojek, dengan Go-Car yang sudah mulai berkembang tahun 2015 dan Grab dengan GrabCar yang mulai berkembang tahun 2016. Kedua perusahaan ini memiliki layanan yang serupa dengan layanan taksi dari PT. Blue Bird Tbk.

Semakin banyaknya angkutan umum berbayar berdampak pada semakin ketatnya persaingan, perusahaan dihadapkan pada penentuan strategi dalam pengelolaan usahanya. Faktor yang menjadi penyebab terjadinya hal tersebut yakni adanya persaingan harga dan banyaknya alternatif pilihan jasa angkutan umum. Hal ini menjadikan konsumen semakin selektif. Konsumen akan memilih salah satu diantara pilihan alternatif yang menurutnya sesuai dengan yang diinginkan. Banyak masyarakat saat ini memilih Grab atau Gojek karena banyak keunggulan daripada taksi konvensional seperti tarif yang dikenakan Grab atau Gojek jauh lebih murah dibandingkan tarif taksi konvesional seperti PT. Blue Bird Tbk.

Keunggulan ini membuat Grab dan Gojek lebih banyak memiliki pelanggan. Selain itu, penolakan sopir taksi sempat marak beberapa waktu lalu. Jika ditelusuri yang menjadi penyebab resahnya sopir taksi terlihat dari kinerja 
perusahaan taksi Blue Bird karena sejak 2016 terjadi penurunan kinerja pada perusahaan tersebut.

Pendapatan Blue Bird pada tahun 2015 masih tergolong dalam kinerja pendapatan yang baik. Namun pada tahun 2016, mulai mengalami penurunan pada setiap kuartalnya. Kuartal I-2016, pendapatannya tercatat senilai RP1,27 triliun yang menandakan terjadi penurunan 11 persen dari kuartal sebelumnya yang tercatat sebesar Rp1,43 triliun. Untuk selanjutnya penurunan terus terjadi hingga capaian RP1,03 triliun pada kuartal I-2017. Pendapatan Blue Bird justru mulai membaik pada kuartal-kuartal berikutnya. Pada kuartal III-2017, Blue Bird meraup pendapatan sebesar Rp1,05 triliun, naik 1 persen dari kuartal II-2017 sebesar Rp1,04 triliun. Namun pendapatan yang membaik ini belum sesuai dengan kinerja di 2015 lalu.

Turunnya pendapatan taksi PT. Blue Bird Tbk. tidak lepas dari kalahnya bersaing dengan Gra/Gojek yang disebabkan oleh tarif yang lebih murah. Direktur PT Blue Bird Tbk Andre Djokosoetono menuturkan, kinerja Blue Bird masih membukukan laba bersih, sehingga tidak akan merampingkan karyawan atau PHK dan penjualan aset-aset perusahaan. Namun, perusahaan akan melakukan efisiensi internal dengan memperketat seleksi rekrutmen karyawan baru. Andre (Direktur PT. Blue Bird Tbk) menuturkan, risiko bisnis ke depan bukan hanya persaingan dengan taksi online saja, tetapi juga dengan moda transportasi lainnya. Untuk itu, dirinya menuturkan, Blue Bird akan terus melakukan peningkatan pelayanan dan mengembangkan penggunaan teknologi. Karena, menurut Andre, konsumen pun pada akhirnya akan memilih moda yang memberikan pelayanan terbaik. 
Penentuan strategi akan dijadikan sebagai landasan dan kerangka kerja untuk mewujudkan sasaran - sasaran kerja yang telah ditentukan oleh manajemen. Penilaian kinerja memegang peranan penting dalam dunia usaha, dikarenakan dengan dilakukanya penilaian kinerja dapat diketahui efektivitas dari penetapan suatu strategi dan penerapannya dalam kurun waktu tertentu. Penilaian kinerja dapat mendeteksi kelemahan atau kekurangan yang masih terdapat dalam perusahaan, untuk selanjutnya dilakukan perbaikan dimasa mendatang. Oleh karena itu dibutuhkan suatu alat untuk mengukur kinerja sehingga dapat diketahui sejauh mana strategi dan sasaran yang telah ditentukan dapat tercapai. Mengantisipasi keadaan tersebut maka perusahaan angkutan umum khususnya PT. Blue Bird Tbk. harus bisa menciptakan kepuasan pelanggan. Untuk dapat memiliki keunggulan dalam persaingan bisnis yang pesat, PT. Blue Bird Tbk. perlu memiliki kerangka kerja sistem pengukuran kinerja yang tepat.

Berdasarkan fenomena di atas maka perlu digunakan suatu model pengukuran kinerja yang mampu mengakomodasi kebutuhan untuk memandang dan menilai PT. Blue Bird Tbk. secara komprehensif dan akurat sampai pada tataran strategis, Kaplan dan Norton (1996:20) dalam mengantisipasi kondisi tersebut, yang didukung dengan canggihnya teknologi komputer serta semakin baiknya sistem manajemen, melalui suatu proyek riset yang panjang, membuat mereka terdorong untuk merancang suatu sistem pengukuran kinerja dari aspek non keuangan yang dinamakan dengan konsep balanced scorecard. Esther (2013) meneliti penilaian kinerja menggunakan balanced scorecard pada 63 perusahaan jasa yang terdapat di Kenya. Benang merah yang dapat diambil dari penelitian 
Esther (2013) bahwa pengukuran kinerja perusahaan dengan menggunakan balanced scorecard tidak hanya melihat dari banyaknya profit yang dihasilkan, melainkan dilihat dari proses yang dilakukan sehingga menghasilkan profit tersebut. Evaluasi kinerja di berbagai tingkatan organisasi, departemen dan individu merupakan kebutuhan para manajer di era sekarang, para manajer dapat mengidentifikasi kelemahan, kekuatan perusahaannya dan meningkatkan kekuatan serta menghilangkan kelemahan perusahaannya (Alidade dan Ghasemi, 2015). Melalui konsep tersebut, perusahaan tidak hanya dapat mengetahui perkembangan keuangan yang telah dicapai tetapi juga dapat memonitor kemajuan yang ingin dicapai perusahaan dengan memaksimalkan sumber daya yang ada (Hery, 2014:47). Menurut Dudin dan Frolova (2016), balanced scorecard adalah alat yang efektif untuk pengelolaan strategis bisnis saat ini.

Metode pengukuran kinerja dengan balanced scorecard terbukti mampu diterapkan dalam strategi manajemen di beberapa perusahaan, salah satunya PT. Blue Bird Tbk. Pengukuran kinerja dengan konsep balanced scorecard sangat dibutuhkan PT. Blue Bird Tbk dalam pencapaian tujuan perusahaan jangka pendek maupun jangka panjang. Kinerja dapat dibagi menjadi keuangan dan non keuangan (Ozturk dan Coskun, 2014). Sudut pandang keuangan balanced scorecard tetap menjadi perhatian utama karena merupakan ikhtisar dari tindakan ekonomi yang telah diambil oleh perusahaan. Tolak ukur keuangan juga digunakan sebagai dasar pengukuran kinerja, namun tolak ukur non keuangan juga digunakan, yang terdiri dari aspek kepuasaan pelanggan, proses bisnis internal, serta pembelajaran dan pertumbuhan. Menurut Widnyani dan Suardana 
(2016), aspek non keuangan juga terdiri dari besarnya pangsa pasar dan tingkat pertumbuhan, kemampuan perusahaan menghasilkan produk yang digemari oleh konsumen, serta pengembangan dan penilaian karyawan termasuk tingkat perputaran karyawan untuk kinerja yang terpadu.

Balanced scorecard menerjemahkan misi dan strategi ke dalam berbagai tujuan dan ukuran, yang tersusun ke dalam empat perspektif, yaitu: perspektif keuangan, perspektif pelanggan, perspektif proses bisnis internal, serta perspektif pembelajaran dan pertumbuhan (Kaplan dan Norton, 1996:22). Menurut Domanovic (2013), balanced scorecard dan strategi berjalan beriringan, balanced scorecard juga merupakan model yang efektif dalam memandu manajer untuk mencapai tujuan strategis. Ada sejumlah alat pengukuran kinerja, namun balanced scorecard hanya digunakan untuk menilai perusahaan apakah efisiensi atau tidak, dan balanced scorecard juga merupakan model yang efektif dalam memandu manajer untuk mencapai tujuan strategis. Ada sejumlah alat pengukuran kinerja, namun balanced scorecard hanya digunakan bersamaan dengan tujuan strategis (Akbarian dkk, 2015).

Balanced scorecard cocok diimplementasikan pada semua jenis entitas bisnis karena semua entitas memerlukan sebuah sistem pengukuran yang mampu menghitung ukuran-ukuran keuangan dan juga non keuangan (Christina dan Sudana, 2013). Keempat perspektif balanced scorecard mempunyai hubungan antara satu dengan yang lain. Penjabarannya merupakan suatu strategik objektif yang menyeluruh dan saling berhubungan dimulai dari dari perspektif pembelajaran dan pertumbuhan, perusahaan mempunyai suatu strategi untuk 
meningkatkan produktivitas dan komitmen personel (Begawan dan Suryanawa, 2013).

Terdapat beberapa penelitian-penelitian sebelumnya yang meneliti kinerja entitas bisnis dengan menggunakan balanced scorecard, yaitu penelitian Wiguna dan Wirawati (2017), meneliti kinerja dari Trans Sarbagita menggunakan balanced scorecard. Pengukuran pada perspektif keuangan yang menggunakan ROI diperoleh hasil bahwa kinerja Trans Sarbagita baik, meskipun terjadi kenaikan dan penurunan di setiap tahunnya. Pengukuran pada perspektif pelanggan yaitu kepuasan pelanggan, menunjukkan bahwa Trans Sarbagita mempunyai kinerja yang baik. Pengukuran pada perspektif proses bisnis internal yang meliputi inovasi yang menunjukkan kinerja Trans Sarbagita yang baik. Pengukuran pada perspektif pembelajaran dan pertumbuhan yaitu kepuasan karyawan Trans Sarbagita juga dapat dikatakan baik.

Penelitian Pika \& Dharmadiaksa (2018), meneliti kinerja dari PT. BPR Sari Sedana menggunakan Balanced scorecard. Pengukuran pada perspektif keuangan yang menggunakan rasio Non Performing Loan (NPL), Beban Operasional terhadap Pendapatan Operasional (BOPO), dan Return on Asset (ROA) menunjukkan kinerja PT. BPR Sari Sedana dalam kondisi baik. Pengukuran pada perspektif pelanggan dilihat dari jawaban responden yang pernyataannya positif adalah sebesar $89,88 \%$ yang menandakan kinerja PT. BPR Sari Sedana adalah baik. Pengukuran pada perspektif proses bisnis internal yang menggunakan pengkuran kapasitas infrastruktur adalah cukup baik. Pengukuran pada perspektif pembelajaran dan pertumbuhan yang menggunakan tingkat 
employee retention dan tingkat kepuasaan karyawan menunjukkan kinerja yang sangat baik/sangat puas.

Penelitian Ompi dan Budiasih (2015), meneliti kinerja dari perusahaan Indosat dan XL menggunakan balanced scorecard. Pengukuran pada perspektif keuangan yang menggunakan Net Profit Margin, ROI dan ROE menunjukkan kinerja XL lebih unggul daripada Indosat. Pengukuran pada perspektif pelanggan yang menggunakan indeks kepuasan pelanggan menunjukkan kinerja Indosat lebih unggl dibandingkan XL. Pengukuran pada perspektif proses bisnis internal yang menggunakan tingkat inovasi dan layanan purna jual menunjukkan kinerja Indosat lebih unggul dari XL. Pengukuran pada perspektif pembelajaran dan pertumbuhan yang menggunakan indeks kepuasan karyawan menunjukkan XL sama unggulnya dengan Indosat.

Penelitian Dewanti dkk. (2016), meneliti kinerja dari Lembaga Perkreditan Desa (LPD) Se-Kecamatan Buleleng dengan menggunakan balanced scorecard. Pengukuran pada perspektif keuangan yang menggunakan ROA, LDR, Capital Adequency Ratio, BOPO dan NPL menunjukkan kinerja LPD SeKecamatan Buleleng pada rasio LDR kurang sehat, namun secara keseluruhan sehat. Pengukuran pada perspektif pelanggan (nasabah), perspektif proses bisnis internal serta perspektif pembelajaran dan pertumbuhan yang ketiganya menggunakan kuesioner menunjukkan kinerja dari LPD Se-Kecamatan Buleleng dari ketiga perspektif tersebut termasuk dalam kategori yang baik.

Penelitian ini dilakukan di PT. Blue Bird Tbk, sebuah organisasi jasa yang bergerak di bidang transportasi. Menurut Dincer dkk. (2016), dengan 
dilakukannya pendekatan balanced scorecard juga dapat memberikan hasil yang lebih realistis dibandingkan dengan teknik lainnya, selain itu juga dapat meningkatkan komunikasi antar karyawan di berbagai departemen. Perspektif keuangan dalam Balanced Scorecard mampu memberikan ringkasan konsekuensi tindakan ekonomis yang sudah diambil. Ukuran kinerja keuangan memberikan petunjuk apakah strategi implementasi, dan pelaksanaannya memberikan kontribusi atau tidak kepada peningkatan laba PT. Blue Bird Tbk.. Sedangkan menurut Luis dan Biromo (2007:52) perspektif pelanggan diperlukan untuk mengetahui bagaimana pelanggan dan masyarakat menilai produk atau jasa serta perusahaan secara keseluruhan sehingga informasi tentang pelanggan dapat digunakan untuk menentukan strategi selanjutnya. Di dalam proses bisnis internal PT. Blue Bird Tbk. sangat berkaitan dengan mutu pelayanan, sarana pelayanan oleh masyarakat, dan tingkat efisiensi perusahaan. Luis dan Biromo (2007:16) berpendapat bahwa perspektif pertumbuhan dan pembelajaran berhubungan dengan pengembangan sumber daya manusia, agar masing-masing menjadi pekerja yang kompeten yang akhirnya akan menghasilkan kinerja yang prima bagi organisasi.

Menurut (Hery, 2014:48) pengukuran kinerja merupakan salah satu komponen penting di dalam sistem pengendalian manajemen untuk mengetahui tingkat keberhasilan perusahaan dalam mencapai tujuan yang telah ditetapkan, baik tujuan jangka pendek maupun tujuan jangka panjang. Menurut Surya (2014) pengukuran kinerja merupakan usaha yang dilakukan pihak manajemen untuk mengevaluasi hasil-hasil kegiatan yang telah dilaksanakan oleh masing-masing 
pusat pertanggungjawaban di dalam sistem pengendalian manajemen pada suatu organisasi bisnis.

Pengertian pengukuran kinerja menurut Mulyadi dalam Hery (2014:48), adalah penentuan secara periodic tingkat efektivitas operasional suatu organisasi, badan organisasi dan karyawannya berdasarkan sasaran, standar, dan kriteria yang telah ditetapkan sebelumnya. Pengertian pengukuran kinerja menurut Supriyono dalam Hery (2014:48) adalah sebuah proses untuk menentukan seberapa baik aktivitas-aktivitas bisnis dilaksanakan untuk mencapai tujuan strategis, mengeliminasi pemborosan-pemborosan, dan menyajikan informasi tepat waktu untuk melaksanakan penyempurnaan secara berkesinambungan. Menurut Melnyk dkk. (2013), pengukuran kinerja adalah instrument yang digunakan untuk mengukur efisiensi dan efektivitas tindakan. Literatur menunjukkan bahwa pengukuran kinerja sebagian besar dirancang di seputar ukuran keuangan serta sistem pengendalian operasional dan manajemen (Panicker dan Seshadri, 2013).

Menurut Sari dkk. (2016), pengukuran kinerja aspek non keuangan mendukung tercapainya pengukuran kinerja aspek keuangan. Pengukuran kinerja aspek non keuangan meliputi 3 perspektif yang ada pada balanced scorecard, yaitu pelanggan, proses bisnis internal serta pembelajaran dan pertumbuhan. Penelitian ini selain mengukur kinerja aspek keuangan dan aspek non keuangan taksi, juga ingin membuktikan bahwa kinerja aspek non keuangan mendukung tercapainya kinerja aspek keuangan.

Hery (2014:50) menyatakan bahwa tujuan dan manfaat pengukuran kinerja adalah untuk memotivasi karyawan dalam mencapai sasaran organisasi 
dan dalam mematuhi standar perilaku yang telah ditetapkan sebelumnya agar menghasilkan tindakan dan hasil yang diinginkan. Manfaat pengukuran kinerja yaitu: 1) Mengelola operasi organisasi secara efektif dan efisien melalui pemberian motivasi kepada karyawan secara maksimum. 2) Membantu pengambilan keputusan yang berkaitan dengan karyawan seperti promosi, transfer atau pemberhentian. 3) Menyediakan umpan balik bagi karyawan mengenai bagaimana atasan menilai kinerja mereka. 4) Menyediakan suatu dasar distribusi penghargaan bagi karyawan. 5) Mengidentifikasi kebutuhan pelatihan dan pengembangan karyawan serta menyediakan kriteris seleksi dan evaluasi program pelatihan karyawan.

Balanced Scorecard terdiri dari dua kata yaitu balanced (berimbang) berarti adanya keseimbangan antara kinerja keuangan dan non keuangan, kinerja jangka panjang dan pendek, serta kinerja yang bersifat internal dan eksternal, kemudian scorecard (kartu skor) yaitu kartu yang digunakan untuk mencatat skor kinerja seseorang (Limbu dan Sisdyani, 2016). Menurut Hery (2014:47) menyatakan bahwa pengertian balanced scorecard adalah kumpulan ukuran kinerja terintegrasi yang diturunkan dari misi dan visi perusahaan untuk mendukung strategi perusahaan secara keseluruhan. Menurut Kaplan dan Norton, (1996:16) balanced scorecard merupakan suatu kerangka kerja baru untuk mengintegrasikan berbagai ukuran yang diturunkan dari strategi perusahaan. Balanced scorecard dapat menjadi beberapa bentuk, termasuk pilihan dan berbagai parameter operasional yang berguna dalam pembuatan keputusan. Cara, 
bentuk implementasi dan penggunaan balanced scorecard dapat memiliki efek yang berbeda pada kinerjanya (Rostami dkk., 2015).

Perspektif keuangan dianggap sebagai perspektif terpenting di antara yang lain, terutama dalam kaitannya dengan implementasi strategi dan penilaian kinerja organisasi (Al-Hosaini dan Sofian, 2015). Tujuan keuangan menjadi fokus di semua perspektif lainnya. Balanced scorecard harus menjelaskan strategi perusahaan, dimulai dengan tujuan keuangan jangka panjang, dan kemudian mengaitkannya dengan berbagai ukuran tindakan yang harus diambil berkenaan dengan proses keuangan, pelanggan, proses internal, dan para pekerja serta sistem untuk menghasilkan kinerja ekonomi jangka panjang yang diinginkan perusahaan (Kaplan dan Norton, 1996:14)

Perusahaan melakukan identifikasi pelanggan dan segmen pasar yang akan dimasuki. Segmen pasar merupakan sumber yang akan menjadi komponen penghasilan tujuan keuangan perusahaan. Perspektif pelanggan memungkinkan perusahaan menyelaraskan berbagai ukuran penting kepuasan pelanggan, loyalitas, retensi, akuisisi, dan profitabilitas pelanggan dengan segmen pasar sasarannya (Kaplan dan Norton, 1996:55). Perspektif ini mengidentifikasikan pelanggan dan segmen pasar dimana unit bisnis tersebut akan bersaing serta berbagai ukuran kinerja unit bisnis di dalam segmen sasara Dalam perspektif ini, perusahaan melakukan pengukuran terhadap semua aktivitas yang dilakukan oleh perusahaan baik manajer maupun karyawan untuk menciptakan suatu produk yang dapat memberikan kepuasan tertentu bagi customer dan juga para pemegang saham. Dalam hal ini perusahaan berfokus pada tiga proses bisnis utama yaitu: 
proses inovasi, proses operasi, proses pasca penjualan. (Kaplan dan Norton, 1996:80). Perspektif ini memungkinkan para manajer untuk mengetahui seberapa baik bisnis mereka berjalan, dan apakah produk dan layanannya sesuai untuk kebutuhan pelanggan (Harold dan Thenmozhi, 2014). Menurut Hery (2014:59) melalui proses ini akan memungkinkan bagi perusahaan untuk mencari dan mempertahankan pelanggan dalam pasar yang telah ditargetkan. Perspektif proses bisnis internal juga dapat mengukur efisiensi dan efektivitas perusahaan dalam memproduksi barang dan jasa.

Perspektif pembelajaran dan pertumbuhan mengembangkan tujuan dan ukuran yang mendorong pembelajaran dan pertumbuhan perusahaan. Perspektif pembelajaran dan pertumbuhan memfokuskan keterampilan sumber daya manusia (Stellata, 2013). Menurut Sainaghi dkk. (2013), perspektif ini mengidentifikasikan infrastruktur organisasi yang harus dibangun untuk menciptakan perbaikan jangka panjang. Tujuan di dalam perspektif pembelajaran dan pertumbuhan adalah menyediakan infrastruktur yang memungkinkan tujuan ambisius dalam tiga perspektif lainnya yang ingin dicapai, selain itu tujuan dari perspektif pembelajaran dan pertumbuhan adalah faktor pendorong dihasilkannya kinerja yang istimewa dalam tiga perspektif balanced scorecard yang pertama (Kaplan dan Norton, 1996:109).

Pengukuran kinerja dikatakan sebagai suatu kegiatan pengukuran kerja yang dilihat dari seluruh rantai nilai yang dapat memberikan sebuah umpan balik terhadap manajemen untuk menyediakan informasi mengenai seberapa baik suatu aksi tersebut dapat mewakili sebuah rencana (Widiastiti dan Yadnyana, 2013). 
Metode pengukuran kinerja dengan balanced scorecard terbukti mampu diterapkan dalam strategi manajemen di beberapa perusahaan, salah satunya PT. Blue Bird Tbk. Dalam balanced scorecard, terdapat 4 perspektif yaitu terdiri dari perspektif keuangan, perspektif pelanggan, perspektif proses bisnis internal, serta perspektif pembelajaran dan pertumbuhan. Dari keempat perspektif tersebut, dapat digunakan untuk mengukur dan menganalisis kinerja dari PT. Blue Bird Tbk. dan hasil dari analisis tersebut akan menyimpulkan kinerja dari PT. Blue Bird Tbk. baik atau buruk.

BlueBird adalah sebuah perusahaan yang awalnya bergerak dalam bidang penyedia layanan transportasi umum berupa taxi reguler berdiri pada tahun 1972, lalu berkembang menjadi limousine "Golden Bird", serta usaha sewa mobil. Perusahaan kemudian mengembangkan usaha bus carter "Big Bird" pada tahun 1979. Pada tahun 1993 Blue bird pun menghadirkan layanan taksi eksekutif "Silver Bird". Hingga saat ini Blue Bird Group berkembang menjadi beberapa perusahaan yang bergerak dalam beberapa bidang lainnya. Hal ini menuntut perusahaan Blue Bird untuk dapat tampil lebih baik dalam memberikan layanan kepada masyarakat, dan dengan semakin meningkatnya kebutuhan dalam menggunakan moda transportasi pada saat sekarang ini. BlueBird sebagai perusahaan besar diharapkan dapat memiliki kualitas yang baik dari segala aspek, beberapa diantaranya dapat dilihat dari kualitas para karyawan dan pekerjanya.

Oleh karena itu untuk dapat menyediakan sistem pelayanan yang baik, Blue Bird wajib menyelenggarakan pendidikan awal bagi para pekerjanya, 
dalam hal ini memberi pengarahan yang berkualitas sesuai dengan standar ketentuan pekerja profesional, maupun standar perusahaan yang telah disepakati.Fasilitas training merupakan langkah awal perusahaan untuk memberikan pelatihan kepada karyawan. Saat ini Blue Bird sudah memiliki fasilitas Training Center bagi para calon karyawan baik sebagai calon pengendara maupun karyawan staff untuk seluruh pool yang ada, namun keadaan Training Center saat ini membutuhkan perawatan dan pengembanganfasilitas mauoun prasarana yang sesuai dengan kebutuhan pelatihan.

Dengan adanya perbaikan fasilitas pada interior training center yang sesuai dengan kebutuhan kepelatihan maupun sarana prasarana lainnya, diharapkan dapat mempengaruhi suasana belajar para calon pegawai blue bird dalam menerima arahan yang diberikan. Demi terselenggaranya sistem pelatihan yang berkualitas, dan menghasilkan pegawai yang profesional dalam menyediakan layanan transportasi maupun bidang staff lainnya kepada masyarakat.

\section{METODE PENELITIAN}

Penelitian ini dilakukan pada PT. Blue Bird Tbk. yang terletak di Jalan Raya Sesetan No. 214, Sesetan, Denpasar Selatan, Kota Denpasar, Bali. Alasan dipilihnya lokasi ini sebagai penelitian telah ditulis oleh peneliti di latar belakang masalah. Di samping itu, PT. Blue Bird Tbk. juga memiliki data yang memadai untuk dilakukannya penelitian. 
Objek penelitian ini adalah kinerja dari taksi PT. Blue Bird Tbk.. Kinerja pada taksi PT. Blue Bird Tbk. jika disesuaikan dengan konsep balanced scorecard maka kinerjanya akan ditinjau dengan empat perspektif yaitu perspektif keuangan, perspektif pelanggan, perspektif proses bisnis internal, serta perspektif pembelajaran dan pertumbuhan.

Populasi dalam penelitian ini adalah seluruh karyawan/driver taksi PT. Blue Bird Tbk. dengan jumlah 432 orang. Populasi pelanggan meliputi seluruh pelanggan taksi PT. Blue Bird Tbk sebanyak 2500 orang. Teknik yang digunakan dalam penentuan sampel karyawan/driver dan pelanggan adalah dengan menggunakan teknik nonprobability sampling. Dengan metode ini, maka pengambilan sampel dimana setiap anggota sampel tidak memiliki peluang yang sama untuk dipilih menjadi sampel penelitian. Bagian metode nonprobability sampling yang digunakan adalah metode sampling insidental. Jadi siapa saja yang ditemui peneliti dapat digunakan sebagai sampel, jika orang tersebut dipandang cocok sebagai sumber data.

Ukuran sampel responden karyawan/driver dan pelanggan ditentukan dengan menggunakan rumus Slovin, yaitu:

$$
n=\frac{N}{1+N e^{2}}
$$

Keterangan:

$\mathrm{N}=$ ukuran populasi

$\mathrm{n}=$ ukuran sampel

$\mathrm{e}=$ batas kesalahan

Maka, ukuran responden karyawan/driver taksi PT. Blue Bird Tbk. adalah sebagai berikut: 


$$
\begin{aligned}
& n=\frac{432}{1+432(0,1)^{2}} \\
& n=81,2 \\
& n=80 \text { (dibulatkan) }
\end{aligned}
$$

Maka, ukuran responden pelanggan taksi PT. Blue Bird Tbk. adalah sebagai berikut:

$$
\begin{aligned}
& n=\frac{2500}{1+2500(0,1)^{2}} \\
& n=96,1 \\
& n=95 \text { (dibulatkan) }
\end{aligned}
$$

\section{HASIL DAN PEMBAHASAN}

Berdasarkan uji SPSS, maka didapatkan nilai Cronbach's Alpha. Jika nilai Cronbach's Alpha lebih dari 0,70, maka dapat dikatakan kuesioner yang disebarkan reliable. Berikut hasil uji reliabilitas data responden pada perspektif keuangan PT. Blue Bird Tbk. yang disajikan pada table 1 berikut.

Tabel 1.

Hasil Uji Reliabilitas Data Responden Perspektif Keuangan PT. Blue Bird Tbk

\begin{tabular}{cc}
\hline Cronbach's Alpha & N of Items \\
\hline 0,893 & 10 \\
\hline Sumber: Data diolah, 2018 &
\end{tabular}

Berikut hasil uji reliabilitas data responden pada perspektif pelanggan PT. Blue Bird Tbk. yang disajikan pada table 2 berikut.

Tabel 2.

Hasil Uji Reliabilitas Data Responden Perspektif Pelanggan PT. Blue Bird Tbk

\begin{tabular}{cc}
\hline Cronbach's Alpha & N of Items \\
\hline 0,893 & 10 \\
\hline Sumber: Data diolah, 2018 &
\end{tabular}

Berikut hasil uji reliabilitas data responden pada perspektif proses bisnis internal PT. Blue Bird Tbk. yang disajikan pada table 3 berikut. 
Tabel 3.

Hasil Uji Reliabilitas Data Responden Perspektif Proses Bisnis Internal PT. Blue Bird Tbk

\begin{tabular}{cc}
\hline Cronbach's Alpha & N of Items \\
\hline 0,889 & 10 \\
\hline Sumber: Data diolah, 2018 &
\end{tabular}

Berikut hasil uji reliabilitas data responden pada perspektif Pertumbuhan dan Pembelajaran PT. Blue Bird Tbk. yang disajikan pada table 4 berikut.

Tabel 4.

Hasil Uji Reliabilitas Data Responden Perspektif Pertumbuhan dan Pembelajaran PT. Blue Bird Tbk

\begin{tabular}{cccc}
\hline Cronbach's Alpha & N of Items & \\
\hline 0,889 & 10 & \\
Sumber: Data diolah, 2018 \\
$\begin{array}{c}\text { Perspektif keuangan } \\
\text { merupakan bagian dari pengukuran kinerja }\end{array}$
\end{tabular}

Balanced Scorecard karena keuangan memperlihatkan perencaan dan pelaksanaan strategi suatu perusahaan memberikan keuntungan atau tidak bagi. Pengukuran kinerja perspektif keuangan pada PT. Blue Bird Tbk. (Balanced Scorecard) menggunakan pengukuran Return In Investment (ROI) tahun 2015-2017 dan kuesioner tingkat pengawasan dan pengendalian perusahaan. Berikut perhitungan kinerja perspektif keuangan perusahaan:

ROI digunakan untuk mengukur bagaimana modal yang diinvestasikan ke dalam keseluruhan aktiva untuk menghasilkan keuntungan. Adapun perhitungan ROI adalah:

Return On Investment $(\mathrm{ROI})=\frac{\text { Laba bersih sesudah pajak }}{\text { Total Aktiva }} \times 100 \%$

(2015) Return On Invesment $(\mathrm{ROI})=\frac{826.144 .000 .000}{7.153 .055 .000 .000} \times 100 \%$

$$
\begin{aligned}
& =0,11409726 \times 100 \% \\
& =11,41 \%
\end{aligned}
$$


(2016) Return On Investment $(\mathrm{ROI})=\frac{500.871 .000 .000}{7.300 .612 .000 .000} \times 100 \%$

$$
\begin{aligned}
& =0,06860671 \times 100 \% \\
& =6,86 \%
\end{aligned}
$$

(2017) Return On Investment $(\mathrm{ROI})=\frac{421.735 .000 .000}{6.516 .487 .000 .000} \times 100 \%$

$$
\begin{aligned}
& =0,06471815 \times 100 \% \\
& =6,47 \%
\end{aligned}
$$

Dari perhitungan rumus ROI di atas disajikan ke dalam Tabel 1 berikut:

Tabel 5.

Return On Investment (ROI) PT. Blue Bird Tbk.

\begin{tabular}{cccc}
\hline \multirow{2}{*}{ Tahun } & $\begin{array}{c}\text { Laba Bersih } \\
\text { Setelah Pajak (Rp) }\end{array}$ & Jumlah Aset (Rp) & ROI (\%) \\
\hline 2015 & 826.144 .000 .000 & 7.153 .055 .000 .000 & 11,41 \\
2016 & 500.817 .000 .000 & 7.300 .612 .000 .000 & 6,86 \\
2017 & 421.735 .000 .000 & 6.516 .487 .000 .000 & 6,47 \\
\hline \multicolumn{2}{l}{ Sumber: Data Diolah, 2018 }
\end{tabular}

Berdasarkan pada Tabel 5 di atas dapat dilihat bahwa pada tahun 2015 setiap investasi sebesar Rp 100,- perusahaan menghasilkan laba sebesar Rp 11,41. Kemudian pada tahun 2016 terdapat penurunan Return On Investment (ROI) sebesar 4,55 persen dimana pada tahun 2016 ROI nya menjadi 6,86 persen yang berarti bahwa setiap investasi sebesar Rp 100,- perusahaan menghasilkan laba bersih sebesar Rp 6,86. Kemudian dari tahun 2016 sampai tahun 2017 terdapat penurunan ROI lagi sebesar 0,39 persen dimana pada tahun 2017 ROI nya menjadi 6,47 persen yang berarti bahwa setiap investasi sebesar Rp 100,perusahaan menghasilkan laba bersih sebesar Rp 6,47. Turunnya persentase ROI searah dengan meningkatnya kemampuan perusahaan dalam menghasilkan laba dari investasi yang dimiliki (Wiagustini, Ni Luh Putu; 2014). Penurunan 
persentase ROI tersebut diindikasikan oleh adanya penurunan Laba Bersih (setelah pajak) PT. Blue Bird Tbk. dan jumlah aset usaha.

Analisis pengukuran kinerja PT. Blue Bird Tbk. pada perspektif keuangan menggunakan kuesioner yang menggambarkan tingkat perencanaan perusahaan serta pengawasan dan pengendalian perusahaan. Penilaian dilakukan dengan melihat pernyataan positif dan negatif. Saat proporsi pernyataan positif lebih tinggi dari 60 persen, maka kinerja dari perspektif ini digolongkan pada kualifikasi kinerja baik. Jika responden yang memberikan pernyataan positif berada pada rentangan 0-59 persen, maka PT. Blue Bird Tbk. digolongkan pada kualifikasi kinerja buruk (Ompi dan Budiasih, 2015) Diketahui bahwa pernyataan positif sebesar 97\% (diatas 60\%). Ini berarti kinerja PT. Blue Bird Tbk. pada perspektif keuangan digolongkan pada kualifikasi kinerja baik (Tabel pada Lampiran 1).

Analisis pengukuran kinerja PT. Blue Bird Tbk. pada perspektif pelanggan menggunakan kuesioner yang menggambarkan tingkatr kepuasan pelanggan. Penilaian dilakukan dengan melihat pernyataan positif dan negatif. Diketahui bahwa pernyataan positif sebesar $86 \%$ (diatas 60\%). Ini berarti kinerja PT. Blue Bird Tbk. pada perspektif pelanggan digolongkan pada kualifikasi kinerja baik.

Analisis pengukuran kinerja PT. Blue Bird Tbk. pada perspektif proses bisnis internal menggunakan kuesioner yang menggambarkan tingkat inovasi, operasi dan pasca penjualan. Penilaian dilakukan dengan melihat pernyataan positif dan negatif. Diketahui bahwa pernyataan positif sebesar $88 \%$ (diatas $60 \%$ ). 
Ini berarti kinerja PT. Blue Bird Tbk. pada perspektif proses bisnis internal digolongkan pada kualifikasi kinerja baik.

Analisis pengukuran kinerja PT. Blue Bird Tbk. pada perspektif proses bisnis internal menggunakan kuesioner yang menggambarkan tingkat kepuasan dan motivasi karyawan. Penilaian dilakukan dengan melihat pernyataan positif dan negatif. Diketahui bahwa pernyataan positif sebesar 91\% (diatas 60\%). Ini berarti kinerja PT. Blue Bird Tbk. pada perspektif pertumbuhan dan pembelajaran digolongkan pada kualifikasi kinerja baik.

Implikasi teoritis hasil penelitian ini adalah diketahu bahwa PT. Blue Bird Tbk. kinerjanya sudah cukup baik dari perspektif keuangan serta kinerjanya sangat baik di perspektif pelanggan, proses bisnis internal dan perspektif pertumbuhan dan pembelajaran. Dari hasil tersebut, diharapkan PT. Blue Bird Tbk dapat merencanakan strategi yang tepat di masa mendatang untuk memperbaiki kinerja mereka utamanya pada perspektif keuangannya. Implikasi teoritis lainnya dari hasil penelitian ini adalah dapat memberikan acuan atau bahan refrensi bagi para akademisi yang menggunakan penerapan balanced scorecard dalam pengukuran kinerjanya.

Implikasi praktis hasil penelitian ini adalah dengan diketahuinya kinerja PT. Blue Bird Tbk dari keempat perspektif balanced scorecard, diharapkan dapat berkontribusi dalam pengukuran kinerja PT. Blue Bird Tbk, sehingga PT. Blue Bird Tbk dapat menggunakan hasil penelitian ini sebagai acuan untuk merencanakan strategi yang tepat di masa mendatang. 


\section{SIMPULAN}

Kinerja PT. Blue Bird Tbk pada perspektif keuangan adalah kurang baik. Dilihan dari penilaian ROI yang setiap tahun mengalami penurunan akibat semakin ketatnya persaingan menandakan bahwa kesehatan keuangan PT Blue Bird Tbk buruk namun dari penilaian jawaban responden yang pernyataannya positif menandakan bahwa pengelolaan keuangan PT. Blue Bird Tbk dikatakan baik

Kinerja PT. Blue Bird Tbk pada perspektif pelanggan adalah baik. Ini terlihat dari jawaban responden yang pernyataannya positif (sangat setuju dan setuju), yang menandakan kinerja dari PT. Blue Bird Tbk. pada perspektif pelanggan dapat dikatakan baik.

Kinerja PT. Blue Bird Tbk pada perspektif proses bisnis internal adalah baik. Ini terlihat dari jawaban responden yang pernyataannya positif (sangat setuju dan setuju), yang menandakan kinerja dari PT. Blue Bird Tbk. pada perspektif proses bisnis internal dapat dikatakan baik.

Kinerja PT. Blue Bird Tbk pada perspektif pertumbuhan dan pembelajaran adalah baik. Ini terlihat dari jawaban responden yang pernyataannya positif (sangat setuju dan setuju), yang menandakan kinerja dari PT. Blue Bird Tbk. pada perspektif pertumbuhan dan pembelajaran dapat dikatakan baik.

Seluruhan PT. Blue Bird Tbk diharapkan menggunakan metode Balanced Scorecard untuk mengukur hasil kinerja perusahaan kedepannya. Penilaian Balanced Scorecard mencakup pada aspek keuangan dan non keuangan maka dari itu metode tersebut baik digunakan dalam rangka proses pengambilan keputusan. 
Perspektif pelanggan, PT. Blue Bird Tbk diharapkan agar dapat mempertahankan serta meningkatkan kinerja saat ini, karena masih terdapat ketidapkpuasan responden pelanggan pada tangible (kasat mata) perusahaan serta mempertahankan empathy (empati) perusahaan kepada pelanggan.

Perspektif proses bisnis internal, PT. Blue Bird Tbk diharapkan agar mempertahankan serta meningkatkan kinerja saat ini, karena masih terdapat ketidapkpuasan responden karyawan pada tingkat inovasi perusahaan serta mempertahankan proses operasi perusahaan.

Perspektif pembelajaran dan pertumbuhan, PT. Blue Bird Tbk diharapkan agar mempertahankan serta meningkatkan kinerja saat ini, karena masih terdapat ketidakpuasan responden karyawan pada tingkat kepuasan kerja terutama pada gaji yang diterima serta mempertahankan pelatihan yang diberikan karyawan.

Pada penelitian selanjutnya sebaiknya untuk melakukan pengukuran kinerja perusahaan perlu menambah indikator lain yang digunakan pada masingmasing perspektif, misalnya menambahkan rasio solvabilitas dan rentabilitas pada pengukuran kinerja perspektif keuangan atau memperluas indikator sehingga bisa lebih mempresentasikan keadaan perusahaan.

\section{REFERENSI}

Akbarian, Mojtaba, Esmaeil Najafi, Reza Tavakkoli-Moghaddam, dan Farhad Hosseinzadeh-Lotfi. (2015). A Network-Based Data Envelope Analysis Model in a Dynamic Balanced Score Card. Mathematical Problem in Engineering, hal. 1-13

Alidade, Baharer dan Mohammad Ghasemi. (2015). Ranking the Branches of Bank Sepah of Sistam Baluchistan Using Balanced Score Card and Fuzzy 
Multi-Attribute Decision Making Methods. Research Journal of Recent Sciences, 4(1), hal. 17-24

AL-Hosaini, Fahmi Fadhl \& Saudah Sofian. (2015). A Review of Balanced Scorecard Framework in Higher Education Institution (HEIs). International Review of Management and Marketing, 5 (1), hal.26-35.

BlueBird. (2018). Beranda PT. Blue Bird Tbk. Diunduh dari http://www.bluebirdgroup.com/

Christina, N. P. Y., \& Sudana, I. P. (2013). Penilaian Kinerja Pada PT. Adhi Karya dengan Pendekatan Balanced Scorecard. E-Jurnal Akuntansi Universitas Udayana, 5(3), 516-529.

Dewanti, M. A., Wiagustini, L. P., \& Sedana, I. B. P. (2016). Kinerja Lembaga Perkreditan Desa Berbasis Balanced Scorecard Se-Kecamatan Buleleng. EJurnal Ekonomi dan Bisnis Universitas Udayana, 5(5), 1057-1086.

Dincer, Hasan., Umit Hacioglu, \& Serhat Yuksel. (2016). Balanced Scorecardbased Performance Assessment of Turkish Banking Sector with Analytic Network Process. Journal of Decision Sciences Applications, 1 (20), 1-21

Domanovic, V. (2013). The Effectiveness Of The Performance Measurement In Terms Of Contemporary Business Environment. Ekonomski Horizonti, 15(1), $31-44$.

Dudin, M. N., Frolova, E. E., Kucherenko, P. A., Samusenko, T. M., \& Voikova, N. A. (2016). Creating An Affective System Of Education To Prepare Future Human Resources Withing the Context Provided By The Global Shift Toward A "Green Economy." International Journal of Environmental and Science Education, 11(15), 8706-8717.

Esther. W Kairu, Moses O Wafula, Ochieng Okaka, Odhiambo Odera \& Emmanuel Kayode Akerele. (2013). Effect of Balanced Scorecard on Performance of Firms in the Service Sector. European Journal of Bussiness and Management. 5(9), 120-125.

Harold, Lawrence \& M. Thenmozhi. (2014). An Integrated Performance Succes Measurement Framework for Evaluating Banking System Success: An Empirical Study. Journal of Performance Management, 10 (3), 28-55.

Hery. (2017). Balanced Scorecard for Bussiness. Jakarta: PT. Grasindo.

Kaplan, Robert S \& David P. Norton. (2002). Balanced Scorecard: Menerapkan Strategi Menjadi Aksi. Jakarta: Erlangga

Limbu, Wanda Pramudani \& Eka Ardhani Sisdyani. (2016). Evaluasi Kinerja Dinas Pendapatan Daerah Kota Denpasar Berbasis Balanced Scorecard. E- 
Melnyk, Steven A., Umit Bititci, Ken Platts, Jutta Tobias, \& Bjorn Andersen. (2013). Is Performance Measurement and Management Fitfor The Future. Management Accounting Research, 25, 1-14.

Ompi, P \& Budiasih, I.G.A.N. (2015). Analisis Perbandingan Kinerja Perusahaan dengan Metode Balanced Scorecard pada Indosat dan XL. E-Jurnal Akuntansi Universitas Udayana, 1(10), 31-46.

Ozturk, Elif \& Ali Coskun. (2014). A Strategic Approach to Performance Management in Banks: The Balanced Scorecard. Accounting and Finance Research, 3 (3), 151-158

Panicker, Sunita, \& Vinita Seshadri. (2013). Devising a Balanced scorecard to determine Standard Chartered Bank's Performance: A Case Study. International Journal of Bussiness Research and Development, 2 (2), 35-42.

Pika, P. A. Titha Paramitha, \& Dharmadiaksa, Ida Bagus. (2018). Analisis Pengukuran Kinerja Perusahaan dengan Menggunakan Balanced Scorecard pada PT. BPR Sari Sedana. E-Jurnal Akuntansi Universitas Udayana, 2(22), 1253-1280.

Rostami, Malihe, Ahmad Goudarzi \& Mahdi Madanchi Zaj. (2015). Defining Balanced Scorecard Aspects in Banking Industry Using FAHP Approach. International Journal of Economics and Bussiness Administrations, 1 (1), $25-38$.

Sainaghi, Ruggero, Paul Philips \& Valentina Corti. (2013). Measuring Hotel Performance: Using a Balanced Scorecard Perspectives' Approach. International Journal of Hospitality Management, 34 (5), 150-159.

Sari, Suryaningrat Intan, Bagus Wiksuana \& Sri Artini. (2016). Kinerja PT. Bank Perkreditan Rakyat (BPR) Naga Berbasis Balanced Scorecard di Gianyar. EJurnal Ekonomi dan Bisnis Universitas Udayana, 5 (4), 749-774.

Surya, Lusi Setyandarini. (2014). Analisis Kinerja Berbasis Balanced scorecard Pada Koperasi XYZ. E-Jurnal Akuntansi Universitas Udayana, 8 (2), 279293.

Stellata, Annisa. (2013). Analisis Kinerja Bank Umum Syariah Dan Bank Konvensional Dengan Perspektif Balanced Scorecard (Studi Pada Bank Mandi Dan Bank Syariah Mandiri). Naskah Publikasi Sarjana Jurusan Akuntansi pada Fakultas Ekonomi dan Bisnis Universitas Muhammadiyah Surakarta, Jawa Tengah.

Widiastiti, Yenni \& Yadnyana. (2013). Analisis Perbandingan Kinerja PT. BPR Mitra Balijaya Mandiri dan PT. BPR Cahaya Bina Werdhi Dengan 
Noviana Hermanus Djo dan Ida Bagus Dharmadiaksa. Penerapan ...

Pendekatan Balanced Scorecard. E-Jurnal Akuntansi Universitas Udayana, 4 (3), 605-621.

Wiguna, Eggy Prasutha \& Wirawati. (2017). Penerapan Balanced Scorecard Pada Pengukuran Kinerja Trans Sarbagita. E-Jurnal Akuntansi Universitas Udayana 21.2, 21(2), 1072-1100. 